\title{
UTVECKLINGEN AV STRAFFRÄTTSLIGA PÅFÖLJDERNA I FINLAND
}

AV DIREKTÖR, JUR. DR. TAPIO LAPPI-SEPPÄLÄ

The most important long-term change in Finnish sanctioning policy has been the decrease in the rate of imprisonment. At the beginning of the 1950s, the incarceration rate in Finland was four times higher than the average for the rest of Scandinavia. By the early 1990s, the Finnish rate had declined to Nordic levels of around 55-60 prisoners per 100 inhabitants. Yet during the last three years the number of prisoners has increased again, this time by 30\%. For the moment, however, this trend seems to have stalled.

The sanctioning system was subject to a series of partial reforms during the 1970s in the spirit of "humane neo-classicism". During the 1990s, the relatively simple Finnish sanctioning system was supplemented with new community sanctions. An experiment with community service started in 1992. By 1995 it had proved so successful that it was adopted as a permanent part of the sanctioning system. An experiment with juvenile penalties began in 1995. Experiences from this project will be taken into account in connection with a total reform of the juvenile justice system, which is now in preparation.

The implementation of both community service and juvenile penalties has clearly demonstrated the need for further supplementing the sanctioning system with measures suited for persons suffering from alcohol and drug abuse problems. Plans for a new type of sanction - contract treatment - are ready and waiting for implementation (and financial re-sources).

The nature and purpose of the prison sentence have undergone gradual change, reflecting both the results of new rehabilitation research and the fact that more prisoners are suffering from severe drug and intoxicant problems. As a result, Finnish prisons have increased levels of drug testing and supervision. The supply of intoxicant rehabilitation programs has increased, and new targeted cognitive-oriented activity programs (cognitive skills, anger management, and programs for sexual offenders) have been introduced. One purpose of the upcoming overhaul of the prison law is to specify the aims and content of sentence enforcement, as well as the constitutional rights of prisoners.

\footnotetext{
" Title in English: Trends in Penal Sanctions in Finland. Original in Swedish.
} 


\section{Förändringar och reformer i kriminalpolitiken}

Ett minskat antal fångar 1960-1990. - Kritiken av tvångsvården och den nya inriktningen inom kriminalpolitiken - den "humana nyklassicismen" - ledde under 1970-talet i Finland framför allt till en systematisk strafflindring och färre fängelsestraff. På 1970-talet hade Finland det högsta antalet fångar i hela västliga Europa. I mitten av 1990-talet var det finska fångantalet bland de lägsta inom EU. Anledningen till den här förändringen är delvis strukturell och delvis ett resultat av en systematisk kriminalpolitisk planering och lagstiftning. ${ }^{1}$ En viktig bidragande orsak var också att Finland närmade sig det nordiska samarbetet i lagstiftningsfrågor. En önskan att bli erkänd som en del av den nordiska sociala välfärdsfamiljen underlättade strävandena att sänka antalet fångar till en "internordisk nivå". Från slutet av 1960-talet fram till början av 1990-talet genomfördes närmare 20 reformer, som på olika sätt bidrog till sänkningen av fångantalet. ${ }^{2}$

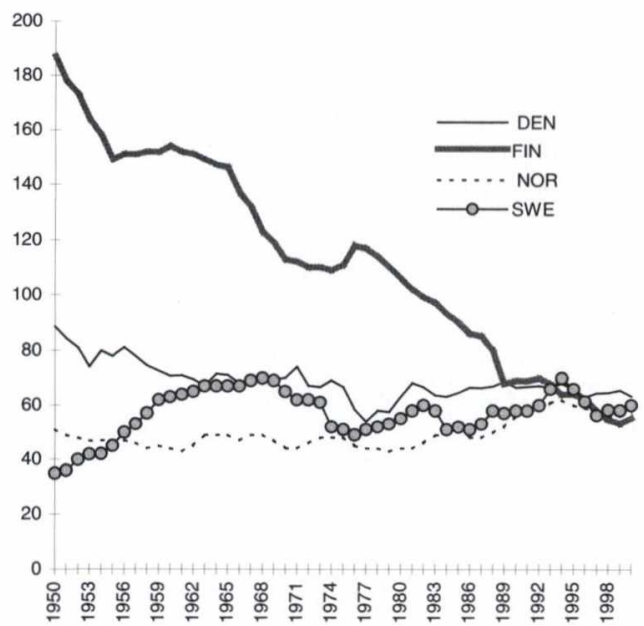

Figur 1. Fångantalet i fyra nordiska länder 1950-2000

\footnotetext{
${ }^{1}$ Se närmare Törnudd 1993 och Lappi-Seppälä 1998.

${ }^{2}$ Och om man jämför uppgifter om fångantalet och den statistikförda strafflagsbrottsligheten i dessa fyra nordiska länder, skulle man kunna konstatera, att även om utvecklingen av fångantalet i Finland har avvikit starkt från de andra nordiska ländernas, har utvecklingen av strafflagsbrotten varit nästan identisk. Resultatet bekräftar den allmänna kriminologiska iakttagelsen, att brottslighetens nivå och struktur beror på andra faktorer än sådana, som hör till straffsystemet. Utvecklingen av brottsligheten i de nordiska länderna har en liknande profil, eftersom de sociala och ekonomiska strukturerna som väsentligt påverkar brottsmängden är likartade i dessa länder (se närmare Lappi-Seppälä 2000).
} 
Totalrevideringen av den finska strafflagen. - Efter olika delreformer av straffsystemet på 1970-talet, övergick man under 1980- och 1990-talen till att stegvis genomföra en helhetsreform av strafflagen. ${ }^{3}$ Den sista omfattande delreformen gällde reformen av strafflagens allmänna del. Nya stadganden för strafflagens allmänna del (515/2003) trädde i kraft i början av år 2004. Även om reformen inte berörde själva det straffrättsliga påföljdssystemets innehåll, medförde den förändringar i stadgandena om utmätande av straff. Man samlade alla stadganden om grunder för straffutmätning samt påföljdsval i samma kapitel. Reformen berörde dock varken den rådande utmätningsideologin eller sanktionsnivån. "Syftet med förslaget är inte att ge mätningsutövningen en ny kriminalpolitisk riktning. ... Reformen har inte heller som mål att revidera den allmänna straffnivån" (RP 44/2002 s. 11). ${ }^{4}$

Ideologi: Om vård, straff och stöd. - En av de grundläggande utgångspunkterna i den finska nyklassiska påföljdspolitiken har varit en strävan att skilja vårdelementen från straffrätten. Man skulle bibehålla en strikt rollfördelning mellan straff- och social-rätten. I Finland ledde arbetsfördelningen till ett påföljdssystem, som tämligen snabbt utrensades på sina (i och för sig rätt obetydliga) rehabiliterande och socialiserande element. I ansvarsfördelningen mellan staten och kommunen har staten tekniskt sett friskrivit sig ansvaret för eftervården och överfört det på kommunerna, som ansvarar för de allmänna socialtjänsterna.

Den här linjedragningen hade den obestridliga förtjänsten att den avslöjade den dolda bestraffning som fanns inbäddad $\mathrm{i}$ vårdmotiven samt tog upp rättsskyddsaspekterna också i vårdsystemen. Men linjen innebar också ett slags risktagande: Man litade på välfärdsstatens tillväxt och dess förmåga att ta hand om även de svåraste marginalgrupperna. Tyvärr ser det nu ut som om att antagandet, att det allmänna socialväsendet vore villigt och kapabelt att sörja för det tidigare kriminalvårdsklientelet, med alla dess specialproblem, varit för optimistiskt. ${ }^{5}$ De psykvårdsoch missbrukarvårdstjänster som problemgrupperna erbjuds, har beskurits allt mera och på ett sätt som medför att grunden för arbetsfördelningen mellan påföljdssystemet, kriminalvårdsarbetet och socialväsendet bör tas i kritiskt betraktande. I synnerhet utvecklandet av en fungerande eftervård för fångar i Finland kommer att förutsätta en allt fastare sammanjämkning av påföljdssystemet och samhällets stödtjänster. ${ }^{6}$

\footnotetext{
${ }^{3}$ Se närmare Lahti 2000.

${ }^{4}$ Den viktigaste enskilda reformen var att räkna upp rasistiska motiv som en allmän grund för skärpning av straffet. En generell översikt av reformen ges i Matikkala 2003.

${ }^{5}$ Om detta se närmare Lappi-Seppälä 2000 s. 121-122.

${ }^{6}$ Konkreta förslag har samlats i kommittébetänkandet "Mot en brottsfri livskontroll", Kommittébetänkande 2001:2.
} 
När det gäller frågan om "vårdens" innehåll och dess effekter, har situationen också förändrats. Tesen "nothing works" har blivit föremål för en grundlig omvärdering. Nyare kriminologisk forskning visar att man med strukturella och kontrollerat genomförda forskningsbaserade program kan reducera risken för återfall. Även om den kriminalpolitiska historien lär oss att vara försiktiga inför nya forskningsrön, ger de nya rehabiliteringsundersökningarna för fångvården tillräcklig grund för att kritiskt granska några av sina äldre premisser. ${ }^{7}$

Allt detta betyder, att det finns både behov och skäl för en moderat revidering av några av de nyklassiska påföljdspolitikens grundpremisser (men inte av dem alla!). Att ta bort alla stödjande element från straffsystemet, kan medföra, att ingen annan tar hand om problemet. Att anta, att man inte har möjligheter att påverka den dömdes beteende kan medföra att viktiga möjligheter för social omintegration förbises. ${ }^{8}$

Politiken och straffnivån: Mot en stramare kontrollpolitik? - Vid millennieskiftet karaktäriserades kriminalpolitiken av tilltagande kontroll. Denna reaktion kunde å andra sidan på många sätt förutses. Tecken på kriminalpolitikens allmänpolitisering och den punitiva populismens frammarsch har en längre tid varit synliga på andra håll i Europa, och det var endast en tidsfråga när denna diskussionstradition skulle nå Finland. Man har kunnat konstatera ständigt vidgade befogenheter för polisen, begränsat bruk av påföljdseftergift och samhällstjänst, samt strängare straff för våldsbrott och sexualbrott. Den tydligaste signalen var höjningen av minimistraffet för grov misshandel från 6 månaders fängelse till ett års fängelse.

Förändringen återspeglas i antalet fångar. Fångantalet började igen öka. Under tre års tid (1999-2002) ökade antalet fångar med ungefär $30 \%$. Stigningen är en följd både av en ökning i antalet dömda personer och strängare domar, speciellt för våldsbrott. Utlänningar, som ofta dömts just för grova narkotikabrott, utgör en betydande del av det ökade antalet brottslingar. Andra grupper av fångar som ökat är rannsakningsfångar, personer dömda för våldsbrott och bötesfångar.

\footnotetext{
${ }^{7}$ För själva straffpolitikens del förändrar den nya rehabiliteringsforskningen inte slutsatsen att anstaltsstraff skall undvikas in $\mathrm{i}$ det sista. Trots att en rehabiliterande fångvård reducerar återfallsrisken i förhållande till "traditionella" metoder, är det inte motiverat att använda fängelsestraff som metod för att kunna tillämpa ett visst program på den dömde. Det är nämligen så att program som tillämpas utanför fängelsets fot ger ännu bättre resultat (se referenser till exempel i Lappi-Seppälä 2000 s. 123).

${ }^{8}$ Men att av detta dra slutsatsen, att ny rehabiliteringsforskning äntligen har visat att "prison works", skulle innebära att man har lärt sig ganska litet av tidigare erfarenheter (se också not 7). Det är, förstås, fortfarande ytterst viktigt att hålla fast vid den nyklassiska kriminalpolitikens rättsskyddsgarantier.
} 
Tabell 1 visar variationen i fångantalet under de senaste åren i Finland, Sverige, Norge och Danmark. Jämfört med de andra nordiska länderna har fångantalets tillväxt varit lika snabb i Sverige som i Finland. En likadan tendens kunde av allt att döma även finnas i Norge, men där har problem med överfulla fängelser lett till fängelseköer som dämpat tillväxten av antalet fångar som det förs statistik över. ${ }^{9}$

Tabell 1 Medelantal fängar. Absoluta tal och fångar per 100000 av folkmängden

\begin{tabular}{|lcccccc|}
\hline & 1998 & 1999 & 2000 & 2001 & 2002 & 2003 \\
\hline Total antal & & & & & & \\
Finland & 2809 & 2743 & 2855 & 3135 & 3434 & 3578 \\
Sverige & 5156 & 5147 & 5326 & 5708 & 6082 & \\
Norge & 2473 & 2520 & 2562 & 2771 & 2850 & \\
Danmark & 3423 & 3477 & 3382 & 3236 & 3435 & \\
\hline Antal/100 000 invånare & & & & & & \\
Finland & 55 & 53 & 55 & 61 & 66 & 69 \\
Sverige & 58 & 58 & 60 & 64 & 68 & \\
Norge & 56 & 56 & 57 & 57 & 63 & \\
Danmark & 65 & 65 & 63 & 61 & 64 & \\
\hline
\end{tabular}

Källor: Falck et al 2003; Kriminalvården (Sverige); Justitsministeriets Forskningsenhed (Denmark); Nordic Statistical Yearbook 2001-2003

En del av orsakerna till förändringen i Finland kan spåras genom att betrakta samma orsaker som i tiden ledde till sanktionsnivåns sänkning. Bakom 70-talets liberala reformpolitik låg en konsensus om grundläggande kriminalpolitiska linjedragningar bland tjänstemän och kriminalpolitiska aktörer. Samtidigt visade politikerna inte något större intresse för kriminalpolitiska frågor och även massmedian förhöll sig rätt måttfullt till kriminaliteten. ${ }^{10}$ Under 1990-talet förändrades situationen. Starka personer inom den politiska högern ifrågasatte linjerna i "70-talets kriminalpolitik". Kvällstidningarnas rapportering av brottmål ökade betydligt. En del av de reformer som syftat till utvidgad kontroll och strängare straff motiverades också med ett behov att uppfylla landets förpliktelser inom EU.

Också förändringar i brottslighetens karaktär stödde kraven på strängare straff. Genom att gränserna öppnades ökade speciellt den grova narkotikabrottsligheten. Hotet av "östmaffians" landstigning dominerade i ett skede i början av

\footnotetext{
${ }^{9}$ Se referat av Magnus Matningsdal.

${ }^{10}$ Se närmare Lappi-Seppälä 1998.
} 
1990-talet diskussionen om brottsligheten. Vid millennieskiftet var det ungdomsbrottsligheten som var på tapeten, eftersom det kommit fram några enstaka dramatiska ungdomsbrott. Den viktigaste av brottslighetens verkliga förändringar var dock bara ökningen av narkotikabrott. ${ }^{11}$

Brottsoffer och brottsprevention. - Att betrakta påföljdssystemet och sanktionsnivån samt förändringarna i dessa räcker inte för att få en helhetsbild av kriminalpolitiken. Kriminalpolitiken har genomgått viktiga innehållsförändringar också utanför själva straffsystemet. Till de viktigaste förändringarna på 1990talet hör det kraftigt skade intresset för brottsprevention och en ny betoning av brottsoffersynvinkeln. Det pånyttfödda intresset för brottsoffersynvinkeln har framför allt kommit fram i åtgärder som vidtagits för att förebygga våld mot kvinnor och för att erbjuda bättre och mer omfattande stöd för brottsoffer. ${ }^{12}$ Också generella brottsförebyggande åtgärder har tagits allt mera fram på den politiska agendan, i regeringsprogram och i ministeriernas långsiktiga strategiska planering. Att kriminalpolitiska frågor lyfts upp till en högre politisk nivå, har i många länder lett till att man gynnar förenklade verksamhetsmodeller som får genklang hos väljarna. Den här risken har man hittills i stort sett lyckats undvika i Finland. Straffrätten har -- tillsvidare -- fått tämligen liten roll i planerna. I stället för straffrätten har man sökt samarbete mellan olika parter (bland annat kommunerna, näringslivet, kyrkan, medborgarorganisationerna samt enskilda medborgare), med tyngdpunkten på det lokala planet och i social- och situationell brottsprevention. ${ }^{13}$

\footnotetext{
${ }^{11}$ Kriminalitetsutvecklingen har närmare behandlats i referat av Kauko Aromaa.

${ }^{12}$ Se Betänkande av brottsofferkommissionen. Komittébetänkande 2001:5.

${ }^{13}$ Se nationellt brottsförebyggande program "Trygga tillsammans" (http://www.om.fi/3976.htm). Också justitieministeriets rättspolitiska strategi för åren 2002-2012 tar upp "effektivare brottsförebyggande och bred kriminalpolitik", "bättre system för stöd och ersättning till brottsoffer" samt "mångsidigare påföljdssystem" (med betonande av samhällssanktioner) och minskning av återfallsbrottslighet som centrala mål för straffverkställigheten (se http://www.om.fi/850.htm\#03). Statsrådets program för inre säkerhet, som i skrivande stund ännu är under beredning, verkar även i hög grad komma att stöda de grundläggande utgångspunkterna för en välfärdsstatlig kriminalpolitik. Programmet utpekar marginaliseringen som en av de centrala hoten för den inre säkerheten och ser en fungerande socialpolitik som den effektivaste metoden för att motverka tendensen. (Sisäasiainministeriö, luonnos sisäisen turvallisuuden ohjelmaksi 17.3.2004).
} 


\section{Fängelsestraff}

\section{Reformen av füngelsestraffets verkställighet 1975}

Stadgandena gällande verkställigheten av fängelsestraff reformerades på 1970talet i en anda av kritik mot den rådande vårdideologin. Reformen av fängelsestraffets verkställighet (431/1975) innebar, att man övergick från progressivsystemet till normalitetsprincipen: Förhållandena i straffanstalterna skall i mån av möjlighet ordnas att motsvara de livsvillkor som råder i samhället i övrigt. Fångar skulle bl.a. erhålla normal undervisning och normala hälsovårds- och övriga tjänster. Reformen innebar även en utvidgning av möjligheterna att avtjäna straff i öppen anstalt. I det senare syftet kom lagen delvis till korta. Andelen platser inom öppenvården blev på en nivå av 20-25\%, och inga större förändringar har sedermera skett. År 2002 var medelantalet fångar inom anstaltsvården 2643 och inom öppenvården 791 .

\section{Förändringar under 1990-talet}

Reform 1995. - Efter 1975-reformen följde en tyst period på verkställighetsfronten. Nästa betydande lagändring ägde rum i mitten av 1990-talet. Detta hade delvis att göra med växande problem inom anstalterna med droger och missbruk. Med reformen år 1995 (128/1995, RP 66/1994) avsågs en effektivering av missbrukarvården och kontrollen av missbruket i fängelserna. I lagändringen preciserades stadgandena gällande undersökning av fångar samt stadgades om kontrollen av missbruk. I och med lagändringen blev det även möjligt att grunda specialavdelningar för fångar som vill binda sig vid att avstå från alkohol och droger. Denna övervakning grundar sig på fångarnas godkännande och kallas i enlighet med detta för kontraktsavdelning.

Samtidigt ersattes den tidigare arbetsplikten med en utvidgad sysselsättningsförpliktelse. Centrala former för sysselsättning är arbetsverksamhet, studier och aktivitetsprogram. Syftet med arbetandet är att upprätthålla arbetsförmågan och yrkeskunnigheten samt att underlätta utkomstmöjligheterna efter frikännandet.

Reform 1999. - Även de senare reformerna (år 1999) hade som syfte att effektivera drogkontrollen i fängelserna (364/1999, RP 10/1998). Straffanstaltens ledare gavs befogenheter att besluta om utförande av fångars kroppsbesiktning. Förutsättningarna för kroppsvisitering utvidgades och likaså fångens skyldighet att ge urinprov eller andningsprov. Lagen ger även möjlighet att grunda speciella säkerhetsavdelningar (denna möjlighet har inte ännu använts). Dessutom har i lagen intagits förutsättningar för att isolera fångar när avsikten är för att hitta droger eller andra rusmedel som gömts i kroppen. 
I lagen finns även bestämmelser om möjligheten att placera fången för en kortare period i en från straffanstalten avskiljd anstalt eller enhet om syftet är missbrukarvård eller annan målinriktad verksamhet. Under de första åren har denna möjlighet används relativt sparsamt. År 2003 fick allt som allt 39 fångar anstaltsvård utanför straffanstalten.

Organisationsreform 2000. - År 2001 förnyades organisationen för straffens verkställande (se RP 136/2000). Numera svarar Brottspåföljdsverket, som lyder under justitieministeriet, som högsta organ för styrning och administration av fängelsestraffens och samhällspåföljdernas verkställighet. Fångvårdsväsendet är en autonom enhet under brottspåföljdsverket och svarar för verkställighet av fängelsestraff. Kriminalvårdsväsendet lyder likaså under brottpåföljdsverket och har hand om samhällspåföljder. Den sistnämnda organen övertog en stor del av de uppgifter som tidigare handhades av den offentligrättsliga Kriminalvårdsföreningen.

\section{Totalreformen av fängelselagen}

Fängelsestraffkommitté 2001. - Lagstiftningen om verkställighet av fängelsestraff har genomgått åtskilliga delreformer, vilket har gjort lagen ostrukturerad. Den uppfyller inte heller de i grundlagen föreskrivna kraven på lagstiftningens exakthet. Frågor som har att göra med berövande av frihet regleras i flera fall av normer på lägre nivå än lag. Reformen av grundrättigheterna år 1998 innebar att bestämmelser som gäller frihetsbegränsning alltid ska regleras med riksdagslag.

Delvis av dessa orsaker tillsatte Finlands regering en kommitté hösten 1999 med uppgift att bereda ett förslag till totalreform av lagstiftningen om fängelsestraff. Kommittén hade till uppgift bland annat att reformera innehållet $\mathrm{i}$ bestämmelserna om verkställighet av fängelsestraff och häktning samt bestämmelserna om villkorlig frigivning och den föråldrade lagstiftningen om farliga återfallsförbrytare. Kommittén överlämnade sitt betänkande i juni $2001 .{ }^{14}$ Utgångspunkten i totalreformen är att på lagnivå exakt och heltäckande ange fångarnas rättigheter och skyldigheter samt begränsningar i fångarnas grundläggande rättigheter. Meningen är att regeringen skall lämna den slutliga propositionen till riksdagen våren $2004 .^{15}$

\footnotetext{
${ }^{14}$ Fängelsestraffkomitténs betänkande. Kommittébetänkande 2001:16.

${ }^{15}$ Det har nyligen genomförts reformer i andra länder: den danska lagen om verkställighet av straff (1.7.2001), den estniska lagen om verkställighet av straff (1.12.2000), den norska lagen om verkställighet av fängelsestraff (2002).
} 
Målen för verkställigheten. - Fängelsestraffkommittén föreslår att verkställighetens mål skall definieras klarare än tidigare. Enligt förslaget skall målet för straffverkställigheten vara att "öka fångarnas förmåga till ett levnadssätt utan kriminalitet genom att främja deras livshantering och anpassning i samhället" (prop. Kap. $1 \S 1.3$ ). Verkställighetens viktigaste rättesnöre blir härmed den från grundrättigheterna härledbara principen att "verkställighet av fängelse får inte orsaka andra begränsningar i fångarnas rättigheter och förhållanden än de som bestäms i lag eller som nödvändigtvis följer av själva straffet" (prop. Kap. $1 \S$ 3.1). För det andra betonas ett allmänt säkerhetsperspektiv: "Verkställigheten av fängelse skall genomföras så att den är säker för samhället, personalen och fångarna" (prop. Kap. 1 § 3.2). Den tredje grundläggande tanken är att minimera straffets negativa verkningar för fången och att säkerställa fångens välfärd: "Fångarnas möjligheter att upprätthålla sin hälsa och handlingsförmåga skall stödjas. Skador som orsakas av förlusten av frihet skall om möjligt förebyggas” (prop. Kap. 1 § 3.2).

Innehållet $i$ verkställigheten. - Fastän man inte kan motivera användandet av anstaltsstraff med att en anstaltsvistelse kunde förbättra förbrytarens fortsatta sociala anpassning, bör man naturligtvis i användandet av anstaltsstraff (av andra orsaker) sträva efter att straffet inte försvårar förbrytarens framtida sociala anpassning, utan i mån av möjlighet stöder förbrytarens strävanden mot ett liv utan brott. En effekt av kritiken av vårdideologin var tyvärr passivitet gällande utvecklandet av fångvårdsprogram. Nyare preventionsforskning visar att man kan nå ganska goda resultat för att minska brottsåterfall med hjälp av väl planerade program som utvecklar kognitiva färdigheter, problemlösningsförmåga eller rationellt tänkande. På senare tid har man tagit in verksamhetsprogram även i det finska fångvårdsarbetet.

Dessa skräddarsydda målinriktade verksamhetsprogram gäller bara en liten andel av alla fångar. ${ }^{16}$ Vid sidan av dessa är det därför skäl att betona den allmänna principen om att rehabilitering i syfte att öka den sociala anpassningen skall gälla alla fångar. Missbrukarrehabilitering spelar en stor roll i uppfyllandet av principen, inte minst eftersom det hos över hälften av fångarna har konstaterats ett drog- eller rusmedelsberoende som kräver vård. Tabellen visar aktiviteter och program som fångar tagit del av år 2002.

\footnotetext{
${ }^{16}$ En generell utgångspunkt för användandet av programmen är dock uttryckligen fokuseringen på den värsta riskgruppen.
} 
Tabell 2 Målinriktade aktivitetsprogram

\section{Målinriktade aktivitetsprogram eller andra aktiviteter med för att upprätthålla funk- tionsduglighet i finska fängelser samt andelen (\%) fångar som tagit del av dem 2002} $(\mathrm{N}=5$ 182)

Upplysnings- och motivationsprogram för missbrukare $49 \%$

Rehabiliteringsprogram för missbrukare $29 \%$

Aktiviteter för att upprätthålla funktionsförmågan. $10 \%$

Program för våldsförbrytare (Cognitive Self Change, Anger Management) $4 \%$

Cognitive skills -program $1 \%$

Program för sexualförbrytare (STOP) $<1 \%$

En plan för strafftiden. - En del av utvecklandet av straffverkställighetens innehåll utgörs av en rekommendation av att man för varje fånge skilt för sig gör upp en plan för strafftiden. Planen skall göras upp för alla fångar oberoende av strafftidens längd. Nuförtiden görs sådana planer bara för fångar som avtjänar straff som är mera än två år (det är klart att planen kan vara mindre grundlig om strafftiden är mycket kort). Planen skall omfatta hela strafftiden och dessutom tiden för villkorlig frigivning. Meningen är att all verksamhet under strafftiden skall grunda sig på denna plan, t.ex. anstaltsplacering, fångarnas verksamhet $\mathrm{i}$ och utanför anstalten, permissioner etc. Planen skall göras upp i en placeringsenhet i början av strafftiden och uppdateras regelbundet under strafftiden.

Lagen innehåller också en bestämmelse som förpliktar fängelsemyndigheterna att samarbeta med de intagna och de intagnas hemkommuner, samt med kriminalvården, andra myndigheter och enskilda personer (t.ex. fångarnas anhöriga). Meningen är också att planen skall öka samarbetet med andra myndigheter och samarbetsgrupper och förbättra informationsutbytet mellan myndigheterna.

Villkorlig frigivning. - Huvudreglerna för villkorlig frigivning skulle stanna oförändrade. En förstagångsintagen skall friges villkorligt efter att ha avtjänat hälften av straffet, och den som har intagits flera gånger efter att ha avtjänat två tredjedelar av straffet. Nuförtiden kan unga lagöverträdare (dvs. de som begått ett brott innan de fyllt 21 och avtjänar sitt straff i ungdomsfängelse) friges när de har avtjänat en tredjedel av straffet. Enligt förslaget skall alla unga fångar (under 21 år) friges efter att ha avtjänat hälften av straffet. 
I syfte att främja fångarnas anpassning i samhället skall man enligt förslaget övergå till ett frigivningssystem i flera steg. Fången kan placeras i övervakad försöksfrihet utanför anstalten under en prövotid på högst sex månader före den villkorliga frigivningen. Detta kräver att beslutet grundar sig på strafftidsplanen och att fången förbinder sig att avstå från rusmedel och iaktta de andra villkoren som har ställts honom eller henne. Försöksfriheten skall också kunna övervakas med tekniska (elektroniska) hjälpmedel.

Efter att fängelsestraffkommittén gett sitt betänkande har det förekommit stark offentlig kritik av systemet med villkorlig frigivning och speciellt av reglerna för verkställigheten av det s.k. reststraffet. Enligt det nuvarande systemet skall den som mist sin rätt till villkorlig frihet avtjäna endast en månad av reststraffet. Kritiken resulterade i att man kommer att skärpa systemet, emedan tillvägagångssättet i skrivande stund är oklart. Antagligen kommer förändringen att innebära att fångantalet i Finland ytterligare ökar.

Tvångsinrättning. - Det nuvarande tvångsinrättningssystemet skall ändras till ett system där farliga våldsrecidivister skall avtjäna hela strafftiden. Villkoren för avtjänandet av hela straffet skall i huvuddrag motsvara de nuvarande bestämmelserna om tvångsinrättning. Beslut som gäller avtjänande av hela straffet skall överföras till allmän domstol. Antalet fångar i tvångsinrättning var 1.4.2004 22.

Livstidsfångar. - För närvarande kan en fånge som avtjänar livstids fängelse friges villkorligt endast genom benådning av republikens president. Enligt förslaget kan livstidsfångarnas möjlighet till villkorlig frihet prövas när tolv år av straffet avtjänats. Meningen är att hovrätten skall fatta beslut om villkorlig frigivning av livstidsfångar. Om en fånge inte friges genom hovrättens beslut, skall man ta beslutet till ny behandling $\mathrm{i}$ hovrätten med två års intervaller. Denna prövning skall gälla vid sidan av och komplettera presidentens benådningsrätt som kvarstår. ${ }^{17}$ Antalet av livstidsfångar var 1.4.2004 102. Mängden har tredubblats inom en 10 års period.

\section{Förvandlingsstraff för böter}

På 1960- och 1970-talen genomfördes en mängd ändringar i strafflagen och påföljdssystemet med syfte att minska antalet bötesfångar. Den viktigaste av dessa reformer var delkriminaliseringen av berusning 1969. År 1977 intogs i lagen en möjlighet att avstå från dömandet till förvandlingsstraff med hänvisning till den dömdes personliga förhållanden. På 1980-talet betonade riksdagens lagutskott

\footnotetext{
${ }^{17}$ Det föreslagna systemet påminner om det system som redan existerar i Danmark och det system som en särskild utredare i Sverige har föreslagit.
} 
(LaUB 4/1986) att man borde effektivera indrivningen av böter, så att det skulle bli möjligt att småningom minska på förvandlandet av böter. I samband med bötesreformen 1999 sökte man en annan lösning på problemet med det oflexibla förvandlingsstraffsystemet, genom att tillämpa allmänna principer om åtgärdseftergift och domseftergift.

Ingen av dessa nyare reformer nådde nämnvärt resultat. I stället började antalet fångar som avtjänade förvandlingsstraff klart öka efter att dagsbotens minimibelopp höjdes år 1999. År 1998 avtjänade i medeltal 96 fångar ett förvandlingsstraff medan motsvarande siffra år 2002 var 190. Situationen i Finland skiljer sig i detta avseende även betydligt från situationen i de övriga nordiska länderna (se tabellen).

Tabell 3 Bötesfångar i medeltal per dag i de nordiska länderna 1996-2001

\begin{tabular}{|lcccccc|}
\hline & 1996 & 1997 & 1998 & 1999 & 2000 & 2001 \\
\hline Finland & 132 & 119 & 96 & 102 & 121 & 149 \\
Norge & 30 & 42 & 36 & 43 & 44 & 47 \\
Sverige & - & - & - & - & - & - \\
Danmark & 94 & 62 & 49 & 51 & 54 & 49 \\
\hline
\end{tabular}

Källa: Sakon muuntorangaistuksen järjestäminen. Oikeusministeriö. Lausuntoja ja selvityksiä 2003:11.

År 2003 publicerade justitieministeriet en plan för att begränsa användandet av förvandlingsstraff. Planen innehöll följande huvudförslag: ${ }^{18}$ (1) Obetalda böter borde inte förvandlas till fängelsestraff $i$ fall där den bötfällde genom utmätning konstaterats vara medellös och det inte ligger $\mathrm{i}$ allmänt intresse att den bötfällde avtjänar ett straff. Detta beslut kunde fattas redan av utmätningsmannen, efter att denne konstaterat att den bötfällde är medellös. (2) Böter som dömts för brott som begåtts av en person under 18 år får inte omvandlas till förvandlingsstraff. ${ }^{19}$ (3) Dagsbotens förvandlingsrelation förmildras så att tre dagsböter kommer att motsvara en dags fängelse (för tillfället är relationen 2/1). (4) Det föreslås att personer med rusmedelsberoende delvis skulle avtjäna sitt förvandlingsstraff inom rusmedelsvården. De fem första vardagarna skall dock avtjänas i ett fängelse med tillräcklig hälsovårdspersonal.

\footnotetext{
${ }^{18}$ Sakon muuntorangaistuksen järjestäminen. Selvitysmiesten ehdotus. Oikeusministeriö. Lausuntoja ja selvityksiä 2003:11.

${ }^{19}$ Detta förslag står i samband med bestämmelserna gällande villkorligt fängelse, enligt vilka en fängelsedom i denna åldersgrupp alltid förutsätter vägande skäl (se nedan).
} 
Dessa förslag som utredningsmännen framställt kan knappast anses vara väldigt dramatiska speciellt om man jämför med situationen i Sverige där man i praktiken upphört att använda förvandlingsstraff helt och hållet. Trots detta har en del av juristförbunden och domarna förhållit sig kritisk till förslagen. Den grundläggande oron bottnar - fortfarande - i tanken om att reformer av detta slag kommer att resultera $\mathrm{i}$ en inflation av bötesstraffets trovärdighet och i att "man har lov att begå brott utan följder". Det faktum att begränsningarna av förvandlingsstraffet som tagits i bruk i Sverige är klart mera radikala än de som har föreslagits i Finland, och att begränsningarna i Sverige inte har resulterat i större problem av de slag som nämnts ovan, verkar inte spela någon större roll $\mathrm{i}$ den finska diskussionen. I skrivande stund dryftar man i justitieministeriet fortfarande hur man skall fortskrida i saken.

\section{Samhällspåföljder}

\section{1. Översikt}

Det finländska påföljdssystemet har traditionellt varit ganska enkelt, sett från ett nordiskt perspektiv. De huvudsakliga strafftyperna har varit ovillkorligt fängelsestraff, villkorligt fängelsestraff och böter. Samhällspåföljdernas roll har varit rätt liten jämfört med de andra nordiska länderna. Inom den finska nyklassiska påföljdspolitiken, som styrt revideringen av påföljdssystemet sedan 1970-talet, fanns inget nämnvärt intresse för utvecklandet av samhällspåföljder som innefattar samhällsfostrande eller rehabiliterande element. De nya samhällspåföljder som togs i bruk på 1990-talet, samhällstjänsten och ungdomsstraffet för unga, utgjorde onekligen en ändring av linjen. ${ }^{20}$

Samhällspåföljdernas roll har även förstärkts tackvare ändringar i verkställighetsorganisationen. Före år 2001 hade största delen av påföljdssystemets verkställighetsuppgifter i Finland anförtrotts den offentligrättsliga Kriminalvårdsföreningen (KVF). År 2001 innebar revideringen av justitieministeriets organisation att man flyttade samhällspåföljdernas verkställighetsuppgifter från Kriminalvårdsföreningen både till den nya kriminalpolitiska avdelningen, som inrättats vid justitieministeriet och till brottspåföljdsverket, som lyder under samma avdelning. Kriminalvårdsföreningen fortsatte sin verksamhet i stiftelseform med tyngdpunkten i sociala och andra typer av stödjande tjänster. ${ }^{21}$

\footnotetext{
${ }^{20}$ Samhällstjänsten och ungdomsstraffet har båda på sätt och vis fört en tredje dimension till påföljdernas nyklassiska "stegmodell". Fråga är inte längre enbart om ett rättvist förhållande mellan brottets förkastlighet och straffets stränghet, utan fråga är allt oftare också om påföljdens tillämplighet för den dömda, samt om en möjlighet att främja den dömdas livskontroll och hans förutsättningar att klara sig socialt (se även Lappi-Seppälä 2002).

${ }^{21}$ Se ovan II.1.
} 
I Finland utdöms för tillfället årligen ca 3500 samhällstjänststraff, knappa 50 ungdomsstraff och drygt 15000 villkorliga fängelsestraff (av dessa döms de unga till drygt 2000 straff med övervakning). Knappa 1000 gärningsmän meddelas domseftergift. Antalet utdömda böter är ca 35000 och de ovillkorliga fängelsestraffens antal är ca. $8000 .^{22}$

\section{Det villkorliga fängelsestraffet}

Dömande till villkorligt fängelse. - Tidigare kunde en villkorlig fängelsedom i Finland innebära endast ett fängelsestraff. År 1976 utvidgades det villkorliga straffets tillämpningsområde. Samtidigt kopplades användningen av det villkorliga straffet från specialprevention till allmänprevention. År 1989 strävade man efter att begränsa användandet av ovillkorliga fängelsestraff för ungdomar. Enligt de nya stadgandena får en person som begått ett brott innan han fyllt 18 år inte dömas till ett ovillkorligt fängelsestraff "om det inte finns vägande skäl" (VillkstraffL $1.2 \S, 992 / 1989$ ).

År 2000 preciserades det villkorliga straffets användningsförutsättningar. Före 2000 kunde ett fängelsestraff förklaras villkorligt i högst två år, "om inte hänsyn till den allmänna laglydnaden kräver att straffet ådöms ovillkorligt". Kriteriet för den "allmänna laglydnaden" ansågs vara för oprecist med alltför stort rum för tolkning. I de nya stadgandena om användandet av villkorligt straff betonas proportionalitetsprincipen, brottets grovhet samt gärningsmannens tidigare brottslighet.

Ifall ett villkorligt fängelsestraff ensamt för sig anses vara en otillräcklig påföljd, kan lagbrytaren utöver det villkorliga fängelsestraffet dömas till ovillkorligt bötesstraff (tillägsböter). Efter 2000 utvidgades området för tilläggspåföljder så, att man som en skärpning till ett villkorligt fängelsestraff på mer än ett år kan utdöma samhällstjänst mellan 20 och 90 timmar.

Innebörden av villkorligt fängelse. - Det utdömda straffet är villkorligt under prövotiden (1-3 år). Ett villkorligt straff kan verkställas om den dömde under prövotiden begått ett nytt brott för vilket ett fängelsestraff enligt domstolens prövning följer. Misskötsamhet ensamt är således inte en tillräcklig grund för att verkställa ett villkorligt straff.

Ett för unga personer (15-20 år när brottet begåtts) utdömt villkorligt straff kan förenas med övervakning. Majoriteten av villkorligt straffade unga personer ställs under övervakning. Övervakningen består i huvudsak av regelbundna träf-

\footnotetext{
${ }^{22}$ Om samhällspåföljderna i Finland se närmare Frände 2001 s. 348 ff och Lappi-Seppälä 2001 med hänvisningar. Om jämförelser mellan de olika nordiska länderna se Kyvsgaard 2001.
} 
far med övervakaren. I vissa fall används olika program med gruppverksamhet. Övervakningen kan upphävas efter sex månader, ifall en fortsättning av den inte anses var nödvändig. Övervakningen har skötts av kriminalvårdsväsendet eller av privata övervakare som förordnats till uppgiften.

Numeriska uppgifter. - Fängelsestraffets villkorlighet och ovillkorlighet under åren 1950-2000 framgår ur tabellen.

Tabell 5 Villkorligt och ovillkorligt fängelse 1950 - 2000

\begin{tabular}{|ccccc|}
\hline & Ovillkorligt & \multicolumn{2}{c}{ Villkorligt } & Villkorligt \\
& $\mathrm{N}$ & $\mathrm{N}($ alla $)$ & + böter & $\%$ \\
\cline { 1 - 3 } 1950 & 6741 & 2812 &.. & 29,5 \\
1960 & 6900 & 3686 &.. & 34,8 \\
1970 & 10212 & 5215 &.. & 33,8 \\
1980 & 10326 & 14556 & 5803 & 58,5 \\
1990 & 11657 & 17428 & 8472 & 59,9 \\
$2000(*$ & $11560\left(^{*}\right.$ & 13974 & 7146 & 54,7 \\
$2000(* *$ & $8147\left(^{* *}\right.$ & $-"-$ & $-"-$ & 63,1 \\
\hline
\end{tabular}

*) Inkl. Fängelsestraff som har förvandlats till samhällstjänst

**) Exkl. Fängelsestraff som har förvandlats till samhällstjänst

År 1950 förklarades $30 \%$ av fängelsestraffen villkorliga, medan motsvarande procenttal år 1990 var $60 \%$. Det villkorliga fängelsestraffets användning ökade betydligt i synnerhet på 1970-talet. I bakgrunden för denna utveckling låg framför allt en omvärdering av straffen för rattfylleri. Det villkorliga straffet är ett av de centrala medlen genom vilka Finland har lyckats sänka antalet fångar under de senaste årtiondena. På 1980- och 1990-talet har det villkorliga och ovillkorliga straffets användningsandelar förblivit rätt oförändrade.

Andelen villkorliga straff varierar beroende på brottets art. Av fängelsestraff som döms för stöld förklaras en tredjedel villkorliga. Vid ekonomiska brott stiger de villkorliga straffens andel av fängelsestraffen till 70-80\%. Skillnaden förklaras framför allt av brottsåterfall. I sådana brottsgrupper där den dömda oftare har blivit dömd tidigare, är även de villkorliga straffens andel av fängelsestraffen lägre. ${ }^{23}$

\footnotetext{
${ }^{23}$ I diskussionerna har man ofta oroat sig för att samma brottslingar (ofta unga personer) kan dömas till ett flertal nya villkorliga straff. Mycket omfattande anhopningar av straff torde dock vara mera sällsynta än man förmodat. En utredning om saken utvisar att endast $16 \%$, av de personer som år 1992 för första gången dömdes till ett villkorligt straff, blev dömda till ett nytt villkorligt straff under de tre därpå följande åren, och detta skedde i regel endast en gång. Fler än två nya villkorliga straff
} 


\section{Samhällstjänst}

Dömande till samhällstjänst. - En försöksverksamhet med samhällstjänst inleddes i Finland år 1991, till en början i en del av landet och senare som riksomfattande. År 1997 blev samhällstjänsten ett permanent straff. Samhällstjänsten innebär att den dömde utför i domen bestämt antal timmar (20-200) oavlönat arbete under övervakning.

Användningen av samhällstjänst skall prövas vid domstol först i det skedet då man beslutat att döma ut ett ovillkorligt fängelsestraff. I lagen har således intagits ett förfarande i två faser. Domstolen väljer (a) först en straffart utan att ta i beaktande möjligheten att döma ut samhällstjänst och, om denna prövning resulterar i ett ovillkorligt fängelsestraff, skall domstolen (b) pröva möjligheten att döma ut samhällstjänst. Syftet med förfarandet är att säkerställa en faktisk användning av samhällstjänst som ett alternativ till ovillkorligt fängelse, inte som ett alternativ till något lindrigare straff.

Det första villkoret för dömande till samhällstjänst är att gärningsmannen döms till ovillkorligt fängelse och att detta straff inte överskrider åtta månader. För det andra förutsätts att svaranden ger sitt samtycke till samhällstjänst. En tredje förutsättning är att svaranden kan antas klara av samhällstjänsten. Svarandens möjligheter att klara av straffet övervägs av domstolen med stöd av Kriminalvårdsväsendets lämplighetsutredning. ${ }^{24}$ Den fjärde förutsättningen har anknytning till gärningsmannens tidigare brottslighet. Till förutsättningarna för utdömandet av samhällstjänst hör också att beakta huruvida "ovillkorliga fängelsestraff, tidigare samhällstjänststraff eller andra vägande skäl skall anses utgöra hinder för att ett samhällstjänststraff döms ut" (STL 3 §, 1055/1996).

fick endast $2 \%$ av de dömda. Anhopningen var dock i de ungas grupp klart vanligare, men inte heller någon allmän regel. Av de unga som dömts till villkorligt straff döms dryga hälften till ett nytt villkorligt straff. Men av alla unga som dömts på nytt döms tre fjärdedelar till bara ett eller högst två nya villkorliga straff. Av de till villkorligt straff dömda unga under 18 år tillhör $4 \%$ den problemgrupp, där minst fem nya villkorliga fängelsestraff utdömts under åren som följer på det första brottet, och $10 \%$ hör till en grupp, där högst fyra nya villkorliga straff utdömts (se LappiSeppälä 2001 s. 117-118). För dessa unga har i påföljdssystemet sökts efter andra alternativ. Försöksverksamheten med ungdomsstraff är ett av sådana alternativ (se nedan avsnitt IV).

${ }^{24}$ Lämpligheten avgörs i praktiken av Kriminalvårdsväsendets utlåtande. Ifall man avviker från utlåtandet, måste avvikelsen alltid motiveras (se HD 1996:9 och 1998:76).

Som kritiken har konstaterat, kan "lämplighet" som användningskriterium leda till likställighetsproblem när svarandens alkoholproblem utgör ett hinder för samhällstjänst och leder till bruket av anstaltsstraff. Man har strävat efter att minska denna fara genom att förena verkställigheten av påföljden med ett antal sociala stödåtgärder. En mer vittgående lösning skulle emellertid vara att införa ett nytt vårdinriktat alternativ för dem som inte kan klara av samhällstjänst på grund av alkoholproblem (se nedan avsnitt V).

${ }^{25}$ Praxisen har varit relativt flexibel. Ett samhällstjänststraff har enligt högsta domstolens praxis varit möjligt även för en sådan gärningsman som tidigare dömts till flera villkorliga och delvis ovillkorliga fängelsestraff, ifall det dock gått en längre tid sedan dessa brott begåtts (se HD 2000:11). 
Domstolen måste alltid också fastställa antalet samhällstjänsttimmar. Samhällstjänstens längd är minst 20 och högst 200 timmar. Tjänstens längd bestäms i praktiken enligt det ursprungliga fängelsestraffet. I lagens förarbeten intogs en förvandlingstabell som styr lagskipningen. Enligt denna tabell motsvarar en fängelsedag en arbetstimme. ${ }^{26}$

Samhällstjänstens innehåll och verkställighet. - Samhällstjänsten består av ett visst timantal regelbundet oavlönat arbete under tillsyn. Tjänsten avtjänas som 3-4 timmars arbetsperioder, vanligen två dagar i veckan. En viss del av samhällstjänststraffets timmar (högst 10) kan avtjänas genom att anlita tjänster inom missbrukarvården på ett sätt som Kriminalvårdsväsendet godkänner.

Kriminalvårdsväsendet svarar för verkställigheten av straffet.Väsendet skaffar och godkänner tjänstgöringsplatserna och övervakar utförandet av samhällstjänsten. Kriminalvårdsväsendet ingriper vid behov i brott mot tjänstgöringsvillkoren medelst muntliga och skriftliga anmärkningar, och domstolen kan avbryta samhällstjänsten och förvandla straffet (åter) till fängelse.

Utförandet av samhällstjänsten övervakas mycket strängt. $\AA$ andra sidan är övervakningen koncentrerad bara på att trygga ett klanderfritt utförande av tjänsten, och är inte förknippad med andra tillsyns- eller stödjande element. Övervakningen har m.a.o. i Finland inte något självständigt innehåll som en del av samhällstjänststraffet.

Om den dömde handlar i strid med tjänstgöringsplanen eller andra villkor, skall Kriminalvårdsväsendet ge honom en muntlig eller skriftlig anmärkning. Kriminalvårdsväsendet skall vid grövre brott mot villkoren för tjänsten göra en anmälan till allmänna åklagaren. Detta gäller exempelvis sådana fall, där den dömde helt låter bli att infinna sig till tjänsten, avbryter utförandet av tjänsten eller på annat sätt grovt bryter mot villkoren för tjänsten (den dömde t.ex. i berusat tillstånd infinner sig på tjänstgöringsplatsen, vägrar att utföra tjänstgöringsuppgifter eller gör sig skyldig till brott på tjänstgöringsplatsen). Om åklagaren anser att samhällstjänsten skall förvandlas till fängelse, skall han yrka det vid den domstol som i första instans avgjort saken. Om domstolen anser att den dömde grovt brutit mot villkoren för tjänsten, skall domstolen förvandla den outförda delen av samhällstjänsten till ett ovillkorligt fängelsestraff. De redan utförda timmarna skall i sin helhet räknas den dömde tillgodo.

Samhällstjänsten i praktiken. - Statistiska uppgifter om samhällstjänsten finns i tabell 6. Antalet årligen utdömda samhällstjänststraff steg under åren 1992-1996 snabbt till över tretusen (B). De ovillkorliga fängelsestraffens antal sjönk å sin

\footnotetext{
${ }^{26}$ Om tabellen, se Frände 2001 s. 384. Detta förvandlingsförhållande är i praktiken inte så här förmånligt för den som avtjänar ett samhällstjänststraff, då ju en fånge försätts i villkorlig frihet efter att denne avtjänat antingen hälften eller två tredjedelar av sitt straff.
} 
sida i samma takt (A). Samhällstjänsten har således tydligt ersatt ovillkorliga fängelsestraff, vilket också avsikten var.

Det största antalet samhällstjänstdomar utdömdes år 1998. Antalet utdömda samhällstjänststraff sjönk under åren 1998-2000. I bakgrunden ligger eventuellt en lagändring som trädde i kraft 1998. Genom denna ändring begränsade man användningen av samhällstjänst $\mathrm{i}$ återfallssituationer. Numera verkar det som om sänkningen har avstannat.

I tabellen ingår också uppgifter om samhällstjänstens "användningsgrad" (C). Siffran anger hur många procent av alla högst 8 månader långa fängelsedomar som omvandlats till samhällstjänst. Denna utveckling är likartad som den utveckling som beskrivits ovan. Samhällstjänstens andel av de utdömda domarna (användningsgraden) var högst år 1997 (47\%), men efter detta har andelen sjunkit till en nivå på 34-35\%.

Tabell 6 Ovillkorliga fängelsestraff och samhällstjänst 1992-2002

\begin{tabular}{|c|c|c|c|c|c|c|c|c|}
\hline & \multicolumn{3}{|c|}{ DOMSTOLSBESLUT } & \multicolumn{5}{|c|}{ VERKSTÄLLIGHET AV SAMHÄLLSTJÄNST } \\
\hline & $\begin{array}{l}\quad \text { A } \\
\text { Fängelse } \\
\text { (exl. Straf } \\
\text { som har } \\
\text { förvand- } \\
\text { lats till } \\
\text { sht) } \\
\mathrm{N}\end{array}$ & $\begin{array}{l}\text { B } \\
\text { Samhälls- } \\
\text { ff tjänst } \\
\mathrm{N}\end{array}$ & $\begin{array}{l}\quad \text { C } \\
\text { Användnings- } \\
\text { graden \% } \\
\text { (av fängelse } \\
\text { max } 8 \text { mån.) }\end{array}$ & $\begin{array}{c}\text { D } \\
\text { Påbörjare }\end{array}$ & $\begin{array}{l}\quad \text { E } \\
\text { Genom- } \\
\text { förda }\end{array}$ & \begin{tabular}{l}
\multicolumn{1}{c}{$\mathrm{F}$} \\
Avbrotts \\
$\%$
\end{tabular} & $\begin{array}{l}\quad \text { G } \\
\text {-Under } \\
\text { verk- } \\
\text { ställig } \\
- \\
\text { het } \\
1.5 .\end{array}$ & $\begin{array}{l}\quad \text { H } \\
\text { Avtjä- } \\
\text { nade } \\
\text { timmar }\end{array}$ \\
\hline 1992 & 11583 & .. & .. & .. & .. & .. & .. & .. \\
\hline 1993 & 9563 & 563 & 21,6 & .. & .. & .. & .. & .. \\
\hline 1994 & 7699 & 1487 & 25,3 & .. & .. & .. & .. & .. \\
\hline 1995 & 6754 & 2803 & 37,2 & 2375 & 1720 & 11,0 & 696 & 169420 \\
\hline 1996 & 6101 & 3277 & 44,6 & 3041 & 2507 & 11,7 & 952 & 243583 \\
\hline 1997 & 5969 & 3534 & 46,6 & 3206 & 2620 & 13,3 & 1066 & 251862 \\
\hline 1998 & 6652 & 3957 & 43,3 & 3762 & 2933 & 13,6 & 1208 & 275788 \\
\hline 1999 & 7668 & 3658 & 38,1 & 3630 & 2979 & 15,0 & 1287 & 257107 \\
\hline 2000 & 8151 & 3413 & 34,8 & 3315 & 2770 & 13,2 & 1194 & 238129 \\
\hline 2001 & 8352 & 3388 & 34,9 & 3193 & 2711 & 15,2 & 1345 & 254238 \\
\hline 2002 & 8489 & 3311 & 34,3 & 3378 & 2729 & 19,5 & 1335 & 242703 \\
\hline
\end{tabular}




\section{År 2002}

- utdömdes i domstolarna 3311 samhällstjänststraff. Dessa utgjorde $34 \%$ av de fängelsestraff som kunde förvandlas (max. 8 månader).

- inleddes verkställigheten av 3378 samhällstjänststraff. Under året slutfördes 2 729 straff. Av dessa straff måste $19,5 \%$ avbrytas. Före år 2002 varierade avbrottsprocenten (av de straff vars avtjänande inletts samma år) mellan 11-15\%.

- avtjänades 240000 timmar samhällstjänst. Detta skulle motsvara 400-500 fångar i det dagliga fångantalet (om man utgår ifrån att man i brist på samhällstjänst verkligen skulle ha utdömt ett motsvarande ovillkorligt fängelsestraff).

- den 1 maj 2002 var 1335 samhällstjänststraff i verkställighet.

Närmare uppgifter om samhällstjänst vid olika brottstyper ingår i tabell 7.

Tabell 7 Samhällstjänstens användning vid olika brott 2003

\begin{tabular}{|c|cc|c|}
\hline & \multicolumn{2}{|c|}{ Antal samhällstjänstdomar } & $\begin{array}{c}\text { Användningsgrad } \\
\end{array}$ \\
N & $\%$ av alla samhällstjänstdomar & \% av fängelse max. 8 månader \\
\hline Alla brott & 3311 & 100,0 & 34,1 \\
Rattfylleri & 1880 & 56,8 & 49,6 \\
Stöld & 339 & 10,2 & 19,3 \\
Misshandel & 337 & 10,2 & 37,4 \\
Övriga & 755 & 22,8 & 24,3 \\
\hline
\end{tabular}

Över hälften av samhällstjänstdomarna ges för rattfylleri. Straffets användnings$\operatorname{grad}(\%$ av max. 8 månaders fängelsedomar) är alltjämt klart störst vid rattfylleribrott $(50 \%)$. Användningsgraden var $37 \%$ vid misshandelsbrott och $19 \%$ vid stöldbrott.

Ett typiskt samhällstjänststraff är till sin längd 70-90 timmar. Straffets längd har ett tämligen klart samband med att brotten avbryts. Av de avbrutna straffen var under de tidigare åren största delen 91-130 timmar till sin längd.

Aterfall efter samhällstjänst. - Enligt en utredning som fångvårdsavdelningen vid justitieministeriet upprättat, kunde man beträffande återfall i brott märka en liten men systematisk skillnad mellan dem som dömts till samhällstjänst och dem som dömts till fängelsestraff. $55 \%$ av dem som dömts till fängelse gavs en ny "brotts-registerdom" inom tre år. Av dem som dömts till samhällstjänst dömdes 52 \% på nytt inom samma tidsperiod. Andelen återfall i brott hade under fem år stigit 
till $67 \%$ beträffande dem som dömts till fängelse och till $61 \%$ i samhällstjänstgruppen. I utredningen strävade man efter att göra grupperna jämförbara. ${ }^{27}$

En helhetsbedömning. - Erfarenheterna av samhällstjänst har varit klart positiva. Samhällstjänstens popularitet torde ha överraskat t.o.m. de myndigheter och sakkunniga som beredde reformen. Efter den första entusiasmen hade användningsområdet för samhällstjänst nog inskränkts, men sedermera har situationen stabiliserats. Mer oroväckande än detta "naturliga bakslag" är att vissa höga tjänstemän riktat kritik mot samhällstjänsten och dess användningssätt. Utan att ta ställning till hur motiverad denna kritik kan anses vara, ${ }^{28}$ hör det till realiteterna i praktiken, att samhällspåföljdernas fortsatta medvind till centrala delar beror på påföljdernas trovärdighet, och det faktum att ett straff uppfattas som ett tillräckligt klart samhälleligt klander med anledning av en gärning. Man har vid verkställigheten av samhällstjänst strävat efter att försäkra sig om detta genom att strängt ingripa även i mindre förseelser. ${ }^{29}$

\section{Unga lagöverträdare}

Specialbestämmelser gällande de unga. - De i Finland förverkligade särskilda arrangemangen angående unga personer är internationellt sett anspråkslösa. För unga har hos oss tillämpats i princip samma straffsystem som på de fullvuxna, om också i lindrigare form. Att ett brott begås av en 15-17 år gammal person, är en av de allmänna straffnedsättningsgrunderna. Man har i denna åldersgrupp även utvidgat förutsättningarna för åtals- och domseftergift och villkorligt straff. Ett fängelsestraff som utdömts åt en ung person (en person som vid gärningstidpunkten är under 21 år) verkställs i allmänhet i en anstalt med tydligt avvikande förhållanden jämfört med övriga anstalter. En ung person friges även tidigare (efter att 1/3 avtjänats). Då en ung person döms till ett villkorligt straff, omfattar straffet i regel även övervakning, till åtskillnad från övriga gärningsmannagrupper.

Revideringen av ungdomsstraffrätten. - I praktiken är den redan år 1940 stiftade lagen om unga förbrytare (262/1940) alltjämt den viktigaste reformen som gäller de unga. I och med denna lag tog man i bruk största delen av de nuvarande specialarrangemangen som gäller unga personer (åtals- och domseftergift, personundersökning beträffande unga personer, övervakning vid villkorligt straff samt det särskilda ungdomsfängelset). I Finland har man under de senaste årtiondena å

\footnotetext{
${ }^{27}$ Se närmare Muiluvuori 2001.

${ }^{28}$ Om detta, se Lappi-Seppälä 2001 avsnitt III.2.

${ }^{29}$ De till detta straff dömda personernas egna utsagor bekräftar uppfattningen om ett krävande straff; i offentligheten framförda motsatta dubier till trots (se Linderborg 2001 s. 156 ff).
} 
andra sidan offentliggjort talrika planer på att utveckla de unga förbrytarnas påföljdssystem. Detta förberedande arbete ledde emellertid först år 1996 till lagstiftningsåtgärder, då riksdagen godkände förslaget till det nya ungdomsstraffet $(109 / 1996){ }^{30}$ Frågan gällde en regionalt begränsad försöksverksamhet som ursprungligen planerades vara i kraft en treårsperiod (1.2.1997-31.12.1999). Försöksverksamheten har sedermera förlängts till slutet av år 2004.

Ungdomsstraffets målsättningar. - Ungdomsstraffet är ett slags kompromiss mellan den nyklassiska och den sociala och rehabiliterande synvinkeln. En del av motiven hade anknytning till en strävan att undgå användning av det villkorliga straffet i denna åldersgrupp. Ett av ungdomsstraffets mål var att skapa ett ytterligare steg $i$ påföljdssystemet och på detta sätt fördröja ett förlopp som i sista hand leder till ovillkorligt fängelsestraff. Man ställde även klara sociala mål för verkställigheten av påföljden. Man ville förena ungdomstjänsten med element, vars förenande drag utgörs av en strävan att främja den ungas sociala handlingsförmåga och ansvarskänsla. Utöver de sociala målen poängterades även behovet av en konkretisering av påföljderna. Man hoppades att ungdomsstraffet skulle vara en mer konkret påföljd för de unga än det villkorliga straffet.

De första uppgifterna om användningen av påföljden vittnar om en tämligen trög start. Dessa uppgifter, samt den i offentligheten framförda kritiken mot det villkorliga straffet, ledde redan under försöksverksamheten till en justering av lagen om ungdomsstraff. Den år 1998 gjorda lagändringens syfte var att få ett nytt tillämpligt alternativ i s.k. brottskarriärfall redan före det första villkorliga straffet (RP 188/1998). I detta syfte gjorde man ett tillägg i lagen, genom vilket straffets användning kopplades till frågan hur gärningsmannen kommer att anpassa sig $\mathrm{i}$ samhället samt med risken att han begår nya brott. En av de ställda förutsättningarna för dömande till ungdomsstraff var att "dömande till ungdomsstraff skall anses motiverat för att förhindra återfall i brott och för att främja gärningsmannens möjligheter att anpassa sig i samhället”.

Dömande till ungdomsstraff. - En ung person som vid gärningstidpunkten fyllt 15 men inte 18 år kan dömas till ungdomsstraff. Den första förutsättningen för att til??lämpa ungdomsstraff är att "böter med beaktande av hur allvarligt brottet är och omständigheterna vid brottet inte kan anses vara ett tillräckligt straff och vägande skäl inte kräver att ett ovillkorligt fängelsestraff döms ut" (USL $3.1 \S$ ). Genom bestämmelsen bestäms att ungdomsstraffets position på påföljdsstegen är på samma nivå som villkorligt fängelse (alltså mellan böter och ovillkorligt fängelse).

${ }^{30}$ L om försöksverksamhet med ungdomsstraff (1058/1996), RP 109/1996. 
Det räcker emellertid inte med att bestämma att påföljden har en position på samma nivå som villkorligt fängelse. Man måste dessutom göra ett val mellan villkorligt fängelse och ungdomsstraff. Härvid skall man tillämpa det i lagen år 1998 intagna tillägget, enligt vilket påföljden skall tillämpas om "dömande till ungdomsstraff skall anses motiverat för att förhindra återfall i brott och för att främja gärningsmannens möjligheter att anpassa sig i samhället".

Efter att domstolen i sin prövning beslutat sig för ungdomsstraff, skall den dessutom besluta om längden av tjänsten och om övervakningen. Till ungdomsstraff döms i minst $10 \mathrm{och}$ högst 60 timmar. I motiveringarna till regeringens proposition konstateras att "såsom i allmänhet vid straffmätning är utgångspunkten hur allvarligt brottet är och gärningsmannens skuld, utgående från vilka faktorer domstolen prövar antalet timmar ungdomstjänst som skall dömas ut” (RP 109/1996). Det sagda stämmer även till största delen in på fastställandet av tiden för övervakning.

Ungdomsstraffens innehåll. - Ungdomstjänsten innebär regelbundet oavlönat arbete under tillsyn samt uppgifter som utförs under handledning och som främjar den sociala handlingsförmågan (USL 2 §). Man strävar efter att utforma tjänstens innehåll så, att det ökar den ungas ansvarskänsla och befrämjar dennes sociala kontakter. I förarbetena nämns som exempel på tjänsteuppgifter bl.a. olika kurser och studieprogram som lämpar sig för att kartlägga den ungas livssituation. Ett av syftena med försöksverksamheten är just att utveckla och testa modellprogram som genomförs i ungdomstjänsten.

Ungdomsstraffet är alltid förenat med övervakning. Till övervakning döms i minst fyra månader och högst ett år. Övervakningen har som uppgift att stöda och ge handledning åt den som dömts till ungdomsstraff. En del av övervakningen kan genomföras som gruppverksamhet.

Kriminalvårdsväsendet svarar för verkställigheten av ungdomsstraff. Verkställigheten av ungdomsstraffet baserar sig i praktiken på arbetsprogram som utvecklats av kriminalvården och socialförvaltningen.

Om den som dömts till ungdomsstraff handlar i strid med verkställighetsplanen eller med föreskrifter som meddelats med stöd av den, skall Kriminalvårdsväsendet ge en skriftlig anmärkning. Ifall det är frågan om grövre överträdelser (den dömde börjar t.ex. inte utföra ungdomstjänsten eller avbryter den), skall en skriftlig utredning göras till åklagaren. I de mest grova fallen skall åklagaren föra saken till domstol. Domstolen kan förlänga övervakningstiden eller förvandla ungdomsstraffet till ett annat straff som motsvarar den del av ungdomsstraffet som inte har avtjänats.

Rättspraxis.- Fram till år 2000 har årligen drygt 50 ungdomsstraff utdömts. Användningen av straffet ökade tydligt efter revideringen år 1998. År 2003 minskade 
användningen av ungdomsstraffet drastiskt. De vanligaste brotten var olovliga ibruktaganden och stöldbrott, vilka är typiska för unga personer.

Mer än var tredje som påbörjat ungdomstjänst avbryter utförandet av straffet, vilket är ett klart större antal än vid samhällstjänst. Av dessa har en anmärkningsvärt stor del även gjort sig skyldiga till ett nytt eller flera nya brott. Bakom avbrytandet ligger i regel svåra drog- eller alkoholproblem och i vissa fall även svåra mentala problem. Det är uppenbart att ungdomsstraffet i dessa fall som stöd behöver ett avsevärt effektivare vårdsystem än det nuvarande systemet för personer som har problem med narkotika, alkohol och den mentala hälsan.

År 2002 tillsattes en ungdomsbrottslighetskommitté för att planera en totalrevidering av påföljdssystemet beträffande unga förbrytare. Kommittén kom att rekommendera att ungdomsstraffet som tillämpats som försöksverksamhet i vissa områden borde införas i hela landet. Kommittén rekommenderade även att ungdomsstraffet skulle utvidgas att gälla även 18-20 år gamla. ${ }^{31}$

\section{Behandlingsorienterade påföljder: Reformplan för kontraktsvård}

En av de största problemen vid tillämpningen av samhällstjänst har varit det faktum att de som på grund av rusmedelsproblem inte lämpar sig för påföljden måste avtjäna straffet i fängelse. För att svara på denna "likställighetskritik", tillsatte justitieministeriet i februari 2001 en kommission att bereda lagstiftningen gällande kontraktsvård. Kommissionen publicerade sitt betänkande år 2002, och regeringspropositionen skall lämnas till riksdagen (enligt planen) våren 2004. ${ }^{32}$

Påföljden skulle i likhet med samhällstjänst användas framför allt som ett alternativ till ovillkorligt fängelse. Kontraktsvård skulle i huvudsak riktas mot gärningsmän, som inte kan dömas till samhällstjänst på grund av rusmedelsproblem.

Kontraktsvård innebär vård enligt en särskild plan. Påföljden är avsedd för personer vars kriminalitet beror på rusmedelsberoende och som kan antas följa vårdprogrammet och de övriga villkoren för kontraktsvården. Ett villkor för kontraktsvård är dessutom att det kan anses motiverat att sådan vård kan hindra den som vården gäller att begå nya brott och främja dennes möjligheter att klara sig socialt.

Dömande till kontraktsvård skulle förutsätta den åtalades samtycke, och att han förbinder sig till den i domen fastställda vårdplanen och till övriga villkor. Vården kunde bestå av såväl vård $i$ anstalt som vård $i$ frihet. Emedan kontraktsvård skulle vara ett alternativ till ovillkorligt fängelse, skulle i påföljden alltid även ingå en vårdperiod i anstalt.

\footnotetext{
${ }^{31}$ Se Nuorisorikostoimikunnan mietintö. Komiteanmietintö 2003:2.

${ }^{32}$ Se utkast till regeringspropositionen, Sopimushoidon kokeileminen. Oikeusministeriö. Lausuntoja ja selvityksiä 2003:16. Enligt förslaget skall kontraktsvården vara ett regionalt försök som skall pågå under tre års tid.
} 
Kontraktsvården skulle kunna dömas ut i stället för ovillkorligt fängelse på högst åtta månader. Kontraktsvården skulle inte kunna dömas ut om det är möjligt att döma ut samhällstjänst.

Den vård som ingår i kontraktsvården skall ges av en vårdenhet som erbjuder tjänster inom missbrukarvården. Kontraktsvården skall omfatta missbrukarvård dubbelt så lång tid som det ursprungliga fängelsestraffet (dvs. högst 1 år 4 månader). Missbrukarvården kan vara anstaltsvård eller öppen vård (dvs. vård $i$ frihet) eller någon annan slags vård eller deltagande i olika program.

Enligt planen skall kontraktsvården genomföras under kriminalvårdsväsendets tillsyn. Kriminalvården ingår ett avtal med den aktuella enheten om den vård som ingår i planen och om kostnaderna för vården. Meningen är att kostnaderna skall betalas av staten.

Reformen är i princip synnerligen betydelsefull eftersom vård inte för närvarande kan dömas ut som straff för ett brott i Finland. ${ }^{33}$ I praktiken kunde det nya straffet i första hand tillämpas på dem som har missbruksproblem och som gjort sig skyldiga till upprepat rattfylleri samt egendomsbrott eller lindrigare våldsbrott.

\section{Restorativ straffrätt: Medling}

Medlingsförfarandet $i$ Finland. - Ett alternativ att medla brott och tvister inleddes i Finland år 1983. Den i huvudstadsregionen (Vanda) inledda försöksverksamheten bredde relativt snabbt ut sig till övriga delar av landet. Numera finns möjligheten till medlingsförfarande tillgänglig i de flesta av landets 452 kommuner.

Den i Finland ibruktagna medlingsmodellen betonar förfarandets alternativa karaktär. Medlingsförfarandet upplevs inte som en "egentlig" del av påföljdssystemet. Sambandet mellan påföljdssystemet och medlingsförfarandet kommer till synes närmast genom att medling nämns som en grund med stöd av vilken åtals- eller domseftergift kan komma ifråga i samband med brott.

Medlingsförfarandet har varit beroende av kommunernas egen aktivitet. Förfarandet grundar sig även till övriga delar på frivillighet. Medlarna är lekmän och de gör i praktiken oavlönat arbete. Medlarna får emellertid en av kommunen arrangerad kort skolning för uppgiften.

Medlingsförfarandet har, oaktat sin inofficiella karaktär, i Finland uppnått synnerligen omfattande dimensioner. Årligen inleddes ett medlingsförfarande i 5000 brottmål. ${ }^{34}$

\footnotetext{
${ }^{33}$ En annan gränslinje mellan straff och vård, som också kommer att omvärderas i framtiden, gäller psykiskt störda lagöverträdare. Social- och hälsovårdsministeriet kommer att under våren 2004 tillsätta en arbetsgrupp med uppgift att evaluera "kriminalpatienternas" nuvarande vårdsystem.

${ }^{34}$ Om statistiska uppgifter se närmare Iivari 2000 och Lappi-Seppälä 2001.
} 
Medlingsprocessen och den officiella straffprocessen verkar delvis parallellt. Målen kan komma till medlingsförfarande (och tillbaka till straffprocessen) från många olika håll. Medlingsförfarandet i målen inleddes i huvudsak på initiativ av åklagare (ca $45 \%$ ) eller polis (ca $40 \%$ ).

I den som direktiv för medlarna uppgjorda handboken poängteras att man inte på något sätt får utöva påtryckning på parterna i syfte att ingå medling. Trots att medlarens uppgift är att främja ingåendet av medling, måste han även kunna hindra att oskäliga avtal ingås och han måste vid behov avbryta medlingsförfarandet, om förfarandet skulle hota någondera partens ställning. ${ }^{35}$

I medlingsförfarande behandlas närmast egendoms- och våldsbrott. Misshandel (38 \%), skadegörelse (21\%) och stöld (17\%) är typbrott. Ungefär hälften av alla medlingsmål gäller gärningsmän under 18 år. Andelen gärningsmän under 15 år var 14 \% år 1997. Av de mål där ett medlingsförfarande inletts, leder ca $60 \%$ till en medling. Parterna i målet bestämmer avtalets innehåll. Det är vanligen fråga om ett avtal som gäller skadestånd, och skadeståndet betalas i pengar, i vissa fall genom arbete. Avtalet kan även innebära endast en symbolisk ersättning, t.ex. framförande av ursäkt. Avtalen innefattade år 1997 penningersättning i $60 \%$, arbete i $10 \%$ och annat (bl.a. ursäkt) i $30 \%$ av fallen. I ca $90 \%$ av fallen har avtalet hållit.

Reformplanen. - Verkningarna och erfarenheterna av medlingsförfarandet har värderats i flera undersökningar. ${ }^{36}$ Värderingarna har allmänt haft en positiv framtoning. Även polisernas och åklagarnas grundinställning har till största delen varit positiv. Man har närmast oroat sig för hur parternas rättsskydd förverkligas. Bristen på organiserade medlingstjänster i en stor del av landet har allmänt uppfattats som ett allvarligt likställighetsproblem. Emedan medlingsförfarandet även har en inverkan på behandlingen av brottmål i olika myndighetsinstanser, kan avvikande medlingsmöjligheter leda till en olik straffrättslig behandling i likartade fall. På basis av det ovannämnda har kraven på att skapa en fastare riksomfattande organisationsmodell och kraven på att lagstadga medlingsförfarandet ökat. ${ }^{37} \mathrm{I}$ dessa planer föreslås emellertid inte några ändringar i medlingsförfarandets övriga utgångspunkter eller i de principer som tillämpas i medlingsförfarandet.

\footnotetext{
${ }^{35}$ Se Handbok för medlare i brott- och tvistemål 2000, s. 32 ff.

${ }^{36}$ Se hänvisningar i Lappi-Seppälä 2001 s. 131-132.

${ }^{37}$ Se Iivari 2000.
} 
Litteratur:

Falck, Sturla, von Hofer, Hanns \& Storgaard, Annette 2003: Nordic Criminal Statistics 1950-2000. Department of Criminology. Stockholm University. Report 2003:3.

Frände, Dan 2001: Allmän straffrätt. Helsingfors 2001.

Iivari, Juhani 2000: Rikos- ja riita-asioiden sovittelun valtakunnallinen organisointi. Sosiaali- ja terveysministeriö. Työryhmämuistioita 2000:27.

Komiteanmietintö 2001:2: Rikoksettomaan elämänhallintaan. Seuraamusjärjestelmän ja yhteiskunnan tukijärjestelmien yhteensovittamista selvittäneen toimikunnan mietintö. Helsinki 2001. (Mot en brottsfri livskontroll. Betänkande av kommissionen för samordning av påföljdssystemet och de samhälleliga stödåtgärderna, Kommittébetänkande 2001:2).

Komiteanmietintö 2001:5: Rikosuhritoimikunnan mietintö. Helsinki 2001. (Betänkande av brottsofferkommissionen, Kommittébetänkande 2001:5).

Komiteanmietintö 2001:16: Vankeusrangaistuskomitean mietintö. Helsinki 2001. (Fängelsestraffkommitténs betänkande, Kommittébetänkande 2001:16).

Komiteanmietintö 2003:2: Nuorisorikostoimikunnan mietintö. Helsinki 2003. (Undomsbrottskommissionen betänkande, Kommittébetänkande 2003:2).

Kyvsgaard, Britta 2001: Harmoni eller disharmoni mellem de nordiske lande. NTfK 2/2001 s. 89-93.

Lahti, Raimo 2000: Om den nordiska kriminalpolitikens utveckling. NTfK 3/2000 s. 177-192.

Lappi-Seppälä, Tapio 1998: Regulating the prison population. Experiences from a long-term policy in Finland. National Research Institute of Legal Policy 38/1998.

Lappi-Seppälä, Tapio 2000: Kriminalpolitik-Straffrättspolitik. NTfK 2/2000 s. 113-135.

Lappi-Seppälä, Tapio 2001: Samhällspåföljder i det finska påföljdssystemet. NTfK 2/2001 s.111-135.

Lappi-Seppälä, Tapio 2002: "Proportionality and Other Values in the Finnish Sentencing System." I Florens juris et legum. Festskrift till Nils Jareborg (ed. Asp, Petter, Herliz Carl Erik \& Holmqvist, Lena). Upsala 2002.

Linderborg, Henrik 2001: Brott och Straff. En undersökning av samhällstjänsten som straff. Åbo 2001.

Matikkala, Jussi 2003: En översikt över revideringen av de allmänna lärorna i finsk strafflag. I Mohr \& Nemitz (Hrsg.) Strafrecht au nordiscer Perspective. FS-für Karin Cornils. Shaker Verlag. Aachen 2003.

Muiluvuori, Marja-Liisa 2001: Recidivism Among People Sentenced to Community Service in Finland. Journal of Scandinavian Studies in Criminology and Crime Prevention Vol 2 No 1, 2001.

Sakon muuntorangaistuksen järjestäminen. Selvitysmiesten ehdotus: Oikeusministeriö. Lausuntoja ja selvityksiä 2003:11.

Sopimushoidon kokeileminen: Oikeusministeriö. Lausuntoja ja selvityksiä 2003:16.

Sovittelijan opas. Rikos ja riita-asioiden sovittelijan opas. Suomen sovittelun tuki ry: Stakes. Oppaita 35. Helsinki 1999. (Handbok för medlare i brott- och tvistemål)

Törnudd, Patrik 1993: Fifteen Years of Decreasing Prisoner Rates in Finland. National Research Institute of Legal Policy. Research Communication 8/1993.

\section{Adress:}

Rättspolitiska forskningsinstitutet

PB 1200

FIN-00 101 Helsingfors

E-post: tapio.lappi-seppala@om.vn.fi 